\title{
The Hard Power of Natural Resources: Oil and the Outbreak of Militarized Interstate Disputes $^{1}$
}

\author{
Georg Strüver ${ }^{1}$ and Tim Wegenast ${ }^{2}$ \\ ${ }^{1}$ GIGA Institute of Asian Studies \\ ${ }^{2}$ University of Konstanz
}

\begin{abstract}
According to conventional wisdom, strategic natural resources like oil are harmful to international peace. Nonetheless, there is little comparative work on the link between resources and interstate conflicts. Analyzing the impact of oil on militarized interstate disputes on the dyadic level of analysis for the period from 1946 to 2001, this paper shows that oil in fact influences the conflict potential between countries. Results of logistic regressions suggest that absolute oil abundance as well as oil dependence increase the risk of dispute involvement. We find that in particular oil production, oil reserves, oil dependence, and oil exports are associated with a higher risk of initiating conflict while countries enjoying large oil reserves are more frequently the target of military actions. Furthermore, our analysis indicates that the presence of large oil deposits also increase the intensity of international disputes. Relative measures of oil abundance such as per capita oil production, in contrast, do not affect countries' dispute proneness. Increased militarization, the internationalization of intrastate violence, the indulgence of an oil-dependent world community and so-called "classical resource wars"-rather than domestic political mechanisms inherent to the rentier state-are likely to explain our findings.
\end{abstract}

\section{Introduction}

The idea that strategic natural resources-especially oil-promote international conflicts is largely perceived as conventional wisdom. Incidences of violence like the Georgia-Russia crisis in 2008 or Iraq's invasion of Kuwait in 1990 underline the notion that oil-abundant countries are more prone to engaging in interstate disputes. On one hand, resource-rich countries often appear to be the target of

\footnotetext{
Georg Strüver, MA, is a research fellow at the German Institute of Global and Area Studies (GIGA), Hamburg. His current research deals with China's rise in international politics and the country's relations with South America and Central Asia in particular. Further research interests include the foreign policy and international cooperation of authoritarian regimes, as well as the role of religion in violent conflicts and resource conflicts.

Dr. Tim Wegenast is a postdoctoral researcher at the University of Konstanz, Germany, and a research associate at the GIGA Studies. His work on the relationship between natural resource extraction and social conflicts has been published in various journals, including International Interactions, Conflict Management and Peace Science, and International Political Science Review. Other research interests include the role of religion in conflicts and the economic history of inequality.

${ }^{1}$ The authors thank Matthias Basedau and four anonymous reviewers for very helpful comments on previous versions of this manuscript. Funding for writing this article was provided by the German Research Foundation, as part of the research projects "Is Resource Wealth a Risk Factor?" as well as "Governing the Resource-Conflict Nexus."
} 
greedy aggressors in search of scarce and strategically important commodities. On the other hand, they are believed to be the malefactor themselves. For several reasons, we suspect that resource-abundant states tend to adopt a more aggressive foreign policy behavior and may indeed be more tempted to resort to military solutions and initiate interstate disputes.

Above all, resources seem to provide an opportunity for ignoring regular diplomatic means and adopting a more aggressive and oppressive foreign policy. Oil revenues can be used to build up a large military apparatus capable of intimidating any neighbor. Domestically, state leaders of fuel-rich countries often do not depend on the approval of large segments of the society (e.g., because of the regime's lack of political competition or a low tax burden) or are able to buy off political opponents using resource rents. Thus, unilateral political decisions can be made without facing much internal opposition.

Furthermore, the involvement in interstate violence might be promoted by a series of other factors. Being dependent on oil imports, the international community may be more likely to tolerate the aggressive foreign policy of large oil exporters and be less inclined to levy sanctions or to intervene. Finally, resourceproducing countries are often plagued by civil wars that-under certain circumstances, such as the hiding out of insurgents on foreign territory or the creation of large refugee flows - may generate severe international tensions.

Although the aforementioned five explanations (namely "resource wars," military buildup, political autonomy of petrostate leaders, the indulgence by the international community, and the internationalization of internal conflict) may sound plausible, there is surprisingly little quantitative comparative work on the link between resources and international disputes. While a number of case studies have depicted the role of resources in explaining singular international conflicts (e.g., Klare 2001, 2008; Peters 2004; Sharp 2007), large cross-national comparisons are still rare. The main exception is an article by Jeff Colgan $(2010,690)$ which suggests that particularly revolutionary petrostates have a higher propensity to engage in militarized interstate disputes (MIDs), constituting "a special threat to international peace and security." Two other studies find that natural resourcesparticularly if located close to borders - increase the probability of interstate conflicts and the geographic spread of already ongoing disputes (Braithwaite 2006; Caselli, Morelli, and Rohner 2013).

The present paper further contributes to this literature by asking whether countries rich in oil are more frequently involved in $\mathrm{MIDs}^{3}$ compared with states that lack substantial petroleum production or reserves. Employing logit estimations on a large panel of countries for the period from 1946 to 2001, using both an undirected and directed dyadic research designs, we test whether petrostates are more likely to initiate militarized disputes and/or are more frequently the target of militarized aggressions. ${ }^{4}$ Moreover, we explore different causal mechanisms linking oil to militarized disputes. By including directed dyads into our analysis, differentiating between various types of MIDs and especially by employing different

\footnotetext{
${ }^{2}$ In an unpublished manuscript, Indra De Soysa, Eric Gartzke, and Tove Grete Lie (2009) find that dyads with one oil exporter are more likely to be involved in MIDs than dyads of two nonoil or two oil exporters.

${ }^{3}$ The notion of "MID" encompasses five types of international disputes characterized by different escalation levels: no militarized action, threat of force, display of force, use of force, and war. We want to note that our dependent variables are MIDs and that-throughout the paper-we use the terms "militarized interstate dispute," "international dispute," and "international conflict" interchangeably (although international conflict may suggest the use of armed force).

${ }^{4}$ We concentrate on oil as it has been the most important strategic resource for the world economy in the last several decades. Hardly any other resource exhibits the combined features of major industrial and social importance, high international prices and low degree of substitutability, widespread but uneven global distribution, and nonrenewability. In addition, there is also a practical reason we choose to focus on oil: Data on oil production in most countries are largely available.
} 
conceptualizations and operationalizations of petroleum wealth, we seek to add new insights to a still poorly understood research question.

The dyadic estimations show two main results: First, petroleum production (both in absolute terms and as a share of total gross domestic product [GDP]), the size of national oil reserves and-albeit less strongly - the volume of net oil exports increase countries' likelihood of being involved in militarized disputes. In contrast, per capita oil production and per capita oil reserves do not affect countries' risk of militarized dispute involvement. Second, the results of our estimations on directed dyadic data indicate that total oil production increases states' likelihood of initiating disputes while total oil reserves significantly affects countries' risk of both initiating and being the target of MIDs. Differentiating between different types of MIDs, our analysis also reveals that while our oil measures (except for per capita oil wealth) are associated with nonfatal MID involvement, only oil reserves seem to increase the risk of fatal interstate disputes.

The results suggest that certain causal pathways, such as the internationalization of intrastate conflict, higher militarization, the indulgence of the international community, and the greed mechanism associated with so-called "classical resource wars," may explain the more aggressive foreign policy behavior of oil-rich states.

The paper proceeds in the following way: The next section provides a systematic overview of the various pathways and possible causal mechanisms linking oil to MID involvement and points to previous studies on oil-related interstate disputes. The employed quantitative research design is described in the next section, which is followed by the paper's quantitative findings and its discussion. The last section concludes and points to areas of future research.

\section{Resources and Hard Power: The Arguments}

Are resource-abundant countries indeed more belligerent and more often the target of interstate disputes, as is commonly asserted? There are certainly good reasons to suspect so. ${ }^{5}$ Probably the most direct and obvious examples of interstate animosities caused by natural resources are the so-called "resource wars" in which greedy outsiders try to appropriate another countries' commodities. By this reasoning, the (perceived) presence of hydrocarbon reserves may generate incentives for countries to conquer the petroleum-rich territory.

According to Colgan (2010, 665), for example, petrostates are, on average, the targets of about 30 percent more MIDs than oil-scarce countries. The most prominent case in point is probably Iraq's invasion of Kuwait in 1990 in which Saddam Hussein's motivations to take control over the latter's abundant oil reserves are believed to have played a major role. According to many critical voices, the US invasion of Iraq in 2003 (Second Gulf War) was primarily a resource war. ${ }^{6}$ Other prominent examples include Japan's invasion of Indonesia during World War II or the British invasion of Mesopotamia during World War I. Le Billon $(2004,1)$ notes that a series of interventions by regional powers, such as the Ugandan or Zimbabwean military deployment in the Democratic Republic of Congo, were motivated by the conquest of valuable resources.

Another example of so-called "resource wars" involve disputes over commodities located near countries' borderlines. Inheriting borders based on vague or contradictory Spanish maps, Ecuador and Peru, for example, fought over the Cordillera del Cóndor, an area believed to be rich in oil and mineral reserves, for

${ }^{5}$ Colgan $(2013 b)$ provides an insightful and comprehensive review of possible mechanisms linking oil to interstate disputes.

${ }^{6}$ One of these critical voices is David King, the UK government's former chief scientific advisor. The scientist maintains that Iraq's invasion was a resource war and was motivated by the desire of securing energy supplies (see interview in The Guardian on February 13, 2009). 
many years. Other cases of boundary disputes include the Chinese show of force against Vietnam regarding oil field explorations near the Spratly Islands, the dispute between Nigeria and Cameroon over the oil-rich territory in the Bakassi Peninsula Area, and the tensions between Venezuela and Trinidad and Tobago over offshore oil exploration rights or the Chinese-Indonesian conflict triggered by a natural gas field. ${ }^{7}$ Territorial disputes over the exploitation of cross-border oil fields have been among the main reasons for armed conflicts in the Arabian Peninsula (Le Billon and El Kathib 2004). In fact, a recent study (Caselli, Morelli, and Rohner 2013) shows that interstate conflicts are more likely when at least one country has natural resources close to the border or when both countries have natural resources that are located asymmetrically vis-à-vis the border.

Besides typical resource wars, there are more indirect causal mechanisms through which oil may affect international security. ${ }^{8}$ Oil, for example, may also provide the opportunity to gain or maintain hard power (Strüver 2010). In economic terms, revenues from the petroleum sector may provide the central state with a readily available pool of funding for military equipment and personnel. As described by Philippe Le Billon and Fouad El Kathib (2004, 110-12), oil rents that are independent of public taxation may enable rulers to build up a strong military, thereby aggravating conflicts in the Persian Gulf. Recent studies find that oil discoveries and oil production increase military spending in nondemocratic states (Cotet and Tsui 2013; Wright, Frantz, and Geddes 2015).

Centralized resources may make oil-rich countries more capable of engaging in militarized disputes. But are higher internal security expenditures and a larger military apparatus really associated with an increased propensity to initiate (or suffer) an MID? A wide range of International Relations research claims that abundant military capacities indeed lead to a more aggressive state behavior. Benjamin Most and Harvey Starr (1989, 23-46), for example, distinguish between state's opportunity and willingness to use or threaten military force. According to them, military capabilities influence not only opportunity but also willingness, as it maximizes policy makers' choices from among the available options. According to realists, state leaders exploit the opportunities generated by their superior military apparatus (e.g., Mearsheimer 2001). Others assert that higher military spending increases the influence of militarists on policymaking (Hobson 1965). So far, few quantitative studies have tested the relationship between military capabilities and interstate disputes. Susan Sample (1998) finds a strong association between military buildups and the escalation of militarized disputes. In a similar vein, Benjamin Fordham (2004, 632) shows that "military capabilities indeed increase the frequency with which force is used."

Apart from possibly enjoying strong military capabilities that increase the range of military options from which to choose, leaders of resource-rich countries are frequently not accountable to the population, do not face political opposition, and/or do not depend on congressional approval. As shown by Jennifer Gandhi and Adam Przeworski (2006) and Tim Wegenast (2013, 396), heads of states enjoying high resource revenues make fewer institutional concessions-such as establishing a formal legislature or allowing multiple political parties. In many cases, resource-rich countries exhibit stable autocratic regimes (Ulfelder 2007; Wright, Frantz, and Geddes 2015).

Hussein Mahdavy (1970) first discussed the domestic political benefits that oil income brought to the Shah's government in Iran, coining the term "rentier state." Leaders of rentier states enjoy a greater degree of policy autonomy as large rents allow for the funding of rich patronage networks and the buying of political

\footnotetext{
${ }^{7}$ The examples are taken from the dispute narratives provided by the Correlates of War Project (Ghosn, Palmer, and Bremer 2004).

${ }^{8}$ According to Colgan $(2013$ b, 149), resource wars capture "the lion's share of the attention, but it is only one of many plausible causal connections."
} 
consent. Consequently, these leaders face a lower risk of being deposed from office and are less often punished for unpopular foreign policy adventurism. ${ }^{9}$ As shown by Patrick McDonald (2007, 571-72), high nontax revenues (e.g., from oil) exempt governments from their accountability, enabling them to implement and carry out domestically unpopular foreign policies. Such revenues may provide governments with the means to co-opt or repress potential opposition groups and movements that might form in response to the implementation of aggressive foreign policy strategies. Enjoying more political autonomy, leaders of oil-rich states may be more tempted to initiate militarized disputes.

Besides being able to buy political legitimacy, governments of resource-abundant countries are not heavily dependent on taxes as a source of state income. Asserting that oil revenues reduce or eliminate the need to taxation, Samuel Huntington $(1991,65)$ notes that " $[\mathrm{t}]$ he lower the level of taxation, the less reason for publics to demand representation." According to a theoretical model of Timothy Besley and Torsten Persson (2010, 10), states' legal and fiscal capacities decrease with the share of national income generated by natural resources. Not being considerably taxed, citizens are more detached from the political decisionmaking process. They feel less inclined to monitor their incumbents and may have less information about government behavior. Accordingly, the state may feel less compelled to meet the population's demands. Thus, the lack of taxation erodes the basis for citizens to demand accountability from the government. The consequences may be the weakening of state-society linkages (Humphreys 2005). This lack of state responsiveness may encourage government's autonomy and alienation in foreign policy matters and contribute to the exertion of violence against a foreign country (McDonald 2007).

In a nutshell, the argument is that leaders resting on oil revenues are, in general, less constrained by political opposition, enjoy more autonomy in their foreign policy decisions, and are thus less restrained from pursuing a more aggressive foreign policy. In addition to facing weaker domestic opposition, they may also encounter less repression by the international community. Interested in maintaining good relations to guarantee steady oil or gas imports, other countries may be less inclined to sanction resource exporters. Foreign powers depending on oil imports have traditionally shown a strong interest in the stability of, and the maintenance of good relations with, their suppliers (Bellin 2004). David Zweig and Jianhai Bi (2005), for example, show how China successfully watered down a UN sanction against Sudan in order to defend its oil interests there. For the same reason, according to the authors, Beijing is undermining US efforts "to contain Iran's nuclear ambitions by resisting the imposition of sanctions against the Islamic Republic" (Zweig and Bi 2005, 33).

Thus, oil importers often maintain "friendly" relationships with petrostates in an effort to secure access to oil and possibly generate business opportunities for national companies. As noted by Colgan (2013b, 22), such "diplomatic efforts could prevent multilateral cooperation on security issues, such as nuclear nonproliferation, the restriction of small arms trade or the use of land mines, or humanitarian intervention in a troubled state. The absence of such multilateral cooperation could thus extend, deepen, or obstruct the prevention of international conflict." Moreover, big oil consumers may even have an incentive to provide military protection to petrostates, giving them greater discretion and leading to a more radical foreign policy among oil-rich countries (De Soysa, Gatzke, and Lie 2009). Foreign nations often maintain permanent military bases in oil-rich

\footnotetext{
${ }^{9}$ As shown by Colgan (2010, 668-69), leaders such as Saddam Hussein, Ayatollah Khomeini, or Muammar alGaddafi managed to maintain power even after unsuccessful and unpopular foreign policy adventurism. These and other examples of petrostate leaders enjoying political autonomy and showing an aggressive foreign policy behavior without suffering political consequences are explored in greater detail in Colgan (2013b, 161f.) or Colgan (2013a).
} 
countries, such as the United States in the Persian Gulf, France in Gabon, or England in Brunei (Basedau and Lay 2009, 770).

Finally, natural resources may instigate international conflicts by promoting domestic violence. As put forward by a rapidly growing literature, commodities such as oil, gas, or diamonds may-under certain conditions-promote intrastate violence and civil wars (e.g., Collier and Hoeffler 2004; Humphreys 2005; Le Billon 2012; Ross 2012). Internal violence can contribute to interstate disputes-for example, when rebels try to hide behind the border of neighboring countries, when soldiers fight insurgents on foreign territory, or due to cross-border flows of refugees. Also, states often interfere in the internal affairs of conflict-ridden countries by supporting one of the fighting parties (e.g., Salehyan 2008a).

Several authors (Gleditsch, Salehyan, and Schultz 2008; Salehyan 2008b; Schultz 2010) have identified the pathways through which domestic conflict may internationalize. These include the direct military intervention in a given conflict, the deployment of military force by a country experiencing internal violence as a retaliation for other states supporting rebels or in order to conduct counterinsurgency operations in foreign territory and the militarization of a neighboring state as a measure to prevent conflict spill-over or large refugee inflows.

Examples of this interaction between domestic and international conflicts are plenty. The 1,200-mile-long border between Colombia and Venezuela has frequently been the scene of incidents involving Colombian guerrilla and Venezuelan military forces. Venezuela has for years been a refuge for Revolutionary Armed Forces of Colombia (FARC) insurgents. The occasional incursions of Colombian forces into Venezuelan territory to capture the rebels have led to tensions between the two countries. Alleged border violations by guerrilla movements between Uganda and Sudan or Zaire (now DRC) and Uganda, among many others, have also served as motives for international disputes between these states. Examples of interference in civil wars by third parties are Sudan accusing Ethiopia of actively supporting Sudanese rebels, Zaire accusing Rwanda of supporting antigovernment rebels, Colombia's claim that Venezuela's government maintains ties with the rebel organization FARC or Turkey's allegations of Syria supporting the Kurds. ${ }^{10}$ Concerning the incidence of interstate disputes caused by large cross-border refugee flows, Kathleen Newland (1995) notes that the US invasion of Haiti in 1994 was primarily motivated by the attempt to prevent further refugee migration.

The next section tries to find quantitative support for the outlined effect of natural resources on military interstate disputes. By assessing the effects of oil exports as well as oil production and oil reserves in absolute and relative terms (as a share of GDP and per capita) on MID involvement, we test whether the conflictenhancing effect of oil is better explained by weak state-society linkages inherent to the rentier state or by the higher militarization of petrostates, the interaction between intrastate and international conflict, resource wars, and the indulgence of the international oil-dependent community. This way, the paper seeks to contribute to the literature by assessing the potential mechanisms underlying the still poorly understood relationship between oil and international conflicts.

\section{Research Design}

To address the strategic nature of conflict, we employ time-series cross-sectional data and logistic regression estimations within a dyadic framework. ${ }^{11}$ Many

\footnotetext{
${ }^{10}$ For short summaries of these conflicts, see the MID dispute narratives (Ghosn, Palmer, and Bremer 2004).

${ }^{11}$ Tables S1 and S2 of the Online Supporting Material provide an overview and descriptive statistics of the main variables. Several of the independent variables are taken from the Quality of Government Data set (Teorell et al. 2013). Our main models are restricted to a sample of politically relevant dyads in order to make our study more directly comparable with Colgan's (2010) findings. Politically relevant dyads are pairs of states that are either
} 
important correlates explaining the outbreak of interstate disputes require a dyadic level of analysis (e.g., joint democracy, balance of power, trade interdependence, contiguity). The same applies for studying the effect of oil on the onset of interstate dispute: The presence of high levels of oil revenues, for instance, not only alters a government's opportunity structure to engage in aggressive foreign policy behavior or to take up arms. It also leads neighboring states to adapt their foreign policy behavior accordingly. These shifts might increase the risk of a militarized dispute onset if states, for example, choose to engage in an arms race, or they might reduce conflict risks when concessions are made.

We first use undirected dyads as units of analyses to test the general arguments on the contentious nature of oil. Second, we draw on directed dyads to be able to distinguish between directions of state behavior. Our main interests in this part of the analysis relates to comparing the effects of different operationalizations of petroleum abundance on a state's probability of being the target or initiator of a militarized dispute. Thereby, we seek to gather empirical evidence for specific mechanisms underlying the relationship between oil and international conflicts. In order to ensure that the different results for the respective operationalizations of oil abundance are not merely statistical artifacts of the changing sample sizes due to the unequal availability of data over time and place, we will reestimate our main models on a sample of observations for which all data are available.

\section{Dependent Variable: MID}

To measure military conflict, we use Correlates of War data on MID. In the undirected analyses, our dependent variable is a nation's participation in international military conflicts (as an initiator or as a target). In the directed analyses, we code dispute originators as Side A in the case of the "initiating" state, which is "the side that took the first militarized action," and as Side B in the case of the target state (Ghosn, Palmer, and Bremer 2004, 138). Countries that first engage in militarized action (i.e., Side A) are not always the dispute parties striving for the change of the status quo. However, in most MIDs, being the aggressor also involves revisionist attitudes.

MID can be nonfatal. They are historical instances between sovereign states in which the threat, showing off or employment of military force by one country, "is explicitly directed towards the government, official representatives, official forces, property, or territory of another state" (Jones, Bremer, and Singer 1996, 168). In 1998, for instance, the presence of Chinese and Vietnamese vessels in the South China Sea provoked a show of force by the Philippines, the arrest of twenty Chinese fishermen fishing on the Spratly Islands and finally the firing of warning shots at a Chinese fishing boat. No fatalities occurred during this militarized incidence. In contrast, the use of military forces during the Alto Cenepa War between Ecuador and Peru over the Cordillera del Cóndor area in 1995 claimed over one hundred lives.

Previous studies on interstate conflict allude to the necessity of restricting analyses on deadly encounters in order "to reduce bias against the over-reporting of minor military incidences in developed as opposed to developing countries but also ensure a focus on the more severe conflicts" (Bussmann 2010, 145). Other authors note that, as major theories of international conflict seek to explain interstate war, the empirical tests should concentrate on the more relevant disputes (e.g., Oneal, Russett, and Berbaum 2003). However, as we expect natural resources to affect the outbreak of more severe conflicts as well as minor disputes, we do not follow this approach. In the first step of our analyses, we include all MIDs in our 
sample. Second, we control for the impact of conflict intensity by distinguishing between nonfatal and fatal MIDs. Drawing on disputes without casualties provides us with a better test of notions of petrostates' foreign policy aggressiveness which not necessarily needs to escalate to full-scale wars.

\section{Explanatory and Intervening Variables: Oil and Pathways to Conflict}

One of the principal aims of this paper is to gather statistical evidence for specific mechanisms leading oil-abundant states to pursue a more aggressive foreign policy behavior. For this purpose, we believe that differentiating between various operationalizations of oil endowment (particularly absolute and per capita oil production and oil reserves, net oil exports, and oil dependency) is helpful. ${ }^{12}$ The peace and conflict literature has increasingly relied on relative measures such as oil production per capita for testing causal mechanisms inherent to the rentier state. Basedau and Lay (2009), for example, argue that only the availability of very high per capita revenues from oil permits governments to apply the sort of political mechanisms suggested by the rentier state theory (see also Fjelde 2009). By employing different oil measures, we are able to distinguish between different groups of countries. ${ }^{13}$ As will be shown below, these different groups of countries also may differ in their motivations for initiating interstate conflicts or in their propensity of being the target of MIDs.

\section{Weak State-Society Linkages}

As has been outlined above, so-called rentier states are often characterized by weak state-society linkages as they do not rely on taxation for income and, therefore, are released from obligations to their taxpayers (e.g., Huntington 1991; Herb 2005). For this to occur, political leaders need sufficient oil revenues proportional to the total population to be able to enjoy fiscal autonomy and-at the same time-guarantee regime stability by clientelist or repressive practices and redistributive policies. By employing per capita oil production-as opposed to, for example, oil production in absolute terms or as a percentage of GDP-we believe to be better able to target the political opportunity channel inherent to rentier states through which petrostate leaders may embark in foreign policy adventurism.

According to the Index of Economic Freedom from the Heritage Foundation, ${ }^{14}$ the six countries with the lowest total tax revenue in the year 2012 are among the oil-richest states in per capita terms. ${ }^{15}$ Oil-abundant states in pure absolute terms, such as Russia, the United States, Iran, Venezuela, or Mexico, in contrast, enjoy higher tax revenues. Simple bivariate correlation coefficients reveal that per capita oil production is particularly negatively correlated with tax revenue as a percentage of GDP $(r=-.16)$ and positively correlated with higher levels of a state's nontax revenues $(r=.51) .{ }^{16}$ Thus, we assume that per capita oil

\footnotetext{
${ }^{12} \mathrm{At}$ this point, it seems appropriate to note that by differentiating between various operationalizations of oil wealth and oil dependence, we seek to find tentative evidence for specific causal pathways. More research will be needed to uncover the exact mechanisms linking oil to interstate disputes.

${ }^{13}$ In order to illustrate the differences between the oil measures and to identify outlying observations, we report two-way scatterplots of the different operationalizations in Figure S1 of the Online Supporting Material. Correlation matrices of the oil-related independent variables show that while the different oil measures overlap to a certain degree, in most cases, the different measurements are only moderately correlated with each other. Thus, it is plausible to assume that the different oil operationalizations employed throughout the analysis also reflect different dimensions of oil abundance/dependence (see Table S3 of the Online Supporting Material).

${ }^{14}$ See http://www.heritage.org/index/ranking.

${ }^{15}$ These countries are United Arab Emirates, Kuwait, Equatorial Guinea, Oman, Qatar, and Libya.

${ }^{16}$ Data on oil production are taken from Ross (2013). Data for total tax revenue as a percentage of GDP and nontax revenues as proportion of total revenues are taken from Englehart (2009) and McDonald (2007).
} 
wealth is better able to depict the weak state-society linkage mechanism than oil abundance in absolute terms.

The measurement of per capita oil wealth is based on national oil production figures. Oil production is measured in billions of USD and is the product of total oil production and the world price of petroleum in nominal U.S. dollars (USD). To quantify petroleum rents in relation to country size, we divided the value of oil production by countries' total population (Oil production per capita). We acknowledge that a direct measurement of national oil rents depicting the actual disposable income that countries generate from oil exploration or even the governments take of oil rents would have been a more appropriate measurement to test our assumptions. Such data, however, are not available for a large panel of states and the time period under study, and we, therefore, rely on production figures as a proxy. ${ }^{17}$

\section{Internationalization of Intrastate Conflict}

Intrastate conflicts may produce cross-border rebel activity or refugee flows that can motivate international disputes. Several authors have shown that a high degree of oil dependence (as opposed to, e.g., per capita oil abundance) especially increases the risk for intrastate conflict (e.g., Collier and Hoeffler 2004; Basedau and Lay 2009; Ross 2012). Petroleum is often the only relevant source of income within the economies of oil-dependent states and different societal groups have a high incentive to gain access to the key bodies controlling oil production (often through violent means). In the absence of other productive sectors of the economy, leaders of oil-dependent states frequently rely on the military for counterinsurgency measures, thereby trying to keep control over the only available revenuegenerating infrastructure and to guarantee regime survival (Ali and Abdellatif 2015).

However, petroleum revenues within oil-dependent states are seldom high enough to ensure a strong military apparatus and intrastate stability (see Basedau and Richter 2014). Countries, such as Algeria, Angola, Congo Republic, or Nigeria, that are characterized by oil dependency (i.e., oil is the most important source of income relative to other value-adding activities) lack sufficient absolute oil rents in order to build up a large security sector or implement generous and large-scale distributional policies. All of these countries have suffered numerous civil war incidences in the last decades. We, therefore, believe that oil dependence-in contrast to oil abundance-is especially appropriate to measure the mechanisms linking the incidence of intrastate conflict to militarized disputes. To measure oil dependency, we include the variable Oil production/GDP in our models. We divide oil production figures by countries' national GDP.

\section{Militarization and Resource Wars}

In the theoretical part of this paper, we argued that oil may lead to increased military expenditures. Oil provides a direct, nontax source of foreign currency income that can be used to fund controversial military expenditures. In addition, oil revenues often lack transparency and accountability and may be employed for large off-budget military spending. As noted by several authors, governments

\footnotetext{
${ }^{17}$ Alternative World Bank data that calculate oil rents using the value of oil production minus the approximate production costs and which have already been employed by previous studies is only available for the years since 1970. Although taking a rough approximation of production costs into consideration, this data on oil rents also disregard the different size of governmental shares over total oil production. Moreover, as shown in Table S3 of the Online Supporting Material, measures of oil rents are highly correlated with the production data used throughout this study. A robustness check revealed that the use of oil rents as main independent variable yields qualitatively similar results.
} 
need large absolute oil rents in order to develop a big military apparatus capable of offsetting internal and external threats (Basedau and Lay 2009; Ross 2012; Basedau and Richter 2014).

Evidence from very rich oil Emirates in the Persian Gulf seems to corroborate this point. Using data from the Stockholm International Peace Research Institute, Hamid Ali and Omnia Abdellatif (2015) show that the highest military spenders between 1988 and 2012 were Oman, Saudi Arabia, Jordan, and Kuwait (except for Jordan, all of them are characterized by high absolute oil wealth). Pearson's correlation coefficient between absolute oil production and military expenditure is high $(r=.68)$, whereas the correlation with other indicators of oil endowment is considerably lower. ${ }^{18}$

In contrast to per capita indicators of oil wealth or the degree of oil dependency, we thus believe that absolute measures such as total oil production seem more suitable to test the plausibility of the militarization mechanism. In addition, absolute oil wealth also seems to be the appropriate measure in order to test the classical resource wars mechanism described in the previous section. Absolute oil endowment (in particular, countries' total oil reserves) is more likely to turn countries into the target of greedy, expansionist outsiders than a high oil production as a percentage of GDP or petroleum wealth in per capita terms. Hostile neighbors trying to expand their natural resource wealth seem especially interested in the absolute level of oil they may conquer through expansionist military actions. The examples of many international disputes over mineral or oil reserves mentioned above reinforce the claim that particularly large oil deposits are conducive to so-called classical resource wars, as the perception of big oil fields in frontier areas or within disputed maritime borders may promote greedy intentions. The prospect of amassing large oil revenues by future exploration may motivate aggressive and expansionist foreign policy.

To approximate absolute levels of oil rents, we draw on oil production figures (Ross 2013). To deal with the concentration of large quantities of rents from the petroleum sector on a relatively few number of observations (and thereby reduce the outlier-proneness of our estimation), we log-transformed the variable oil production (oil production $[\log ]$ ). This means that the impact of each additional billion USD in available oil income on the involvement in military disputes decreases as oil production increases. ${ }^{19}$ The size of a country's petroleum reserves is taken from Macartan Humphreys (2005). Again, we calculated the natural logarithm of petroleum reserves (petroleum reserves [log]) to avoid the effect that our estimation results are driven by few countries with very large oil reserves. Finally, we included the per capita term of oil reserves (petroleum reserves p.c.) to evaluate how the relative size of a country's petroleum stocks affects the risk of being involved in MIDs.

\section{Indulgence of the International Community}

In order to test the last causal mechanism (the indulgence of an oil-dependent international community), we rely on net oil exports in billions of USD (Ross 2013). We assume that the more oil a country exports, the higher its strategic value for the international community. In order to test this mechanism, oil exports seem a more valid measure than, for example, total production since states with a high absolute oil production such as the United States, Mexico, or Canada do not necessarily figure among the world's top oil exporters.

\footnotetext{
${ }^{18}$ Data on military expenditure come from Correlates of War's National Material Capabilities data set.

${ }^{19}$ Given that the natural logarithm of zero is not defined, we added the value of 1 to the oil variables before logtransforming it. Otherwise, countries with no oil production or no reserves would fall out of our estimations.
} 


\section{Control Variables}

Empirical evidence that domestic political constraints and liberal ideologies maintained in democracies reduce the ability of democratic leaders to pursue aggressive foreign policies is available both at the dyadic and monadic levels of analysis (e.g., Oneal and Russett 1999a; Souva and Prins 2006; Boehmer 2008). In our estimations, we, therefore, control for undirected and directed effects of democracy using three variables: First, we include the Democ variable of the Polity4 data, which measures the democracy level of a country on a scale from 0 to 10 (Jaggers and Gurr 1995). Following the suggestions made by Bennett and Stam (2000a), the undirected estimations contain only the lower democracy score of the two states in the dyad (Democracy score $_{\text {lower level }}$ ). In the directed analyses, in contrast, we include both states' democracy levels separately (Democracy score). Second, we include the variable polity difference in the directed and undirected analyses. It measures the absolute polity difference in the dyad using the Polity2 score of the Polity4 data. Finally, we constructed an interaction term of the initiator's democracy score and the polity difference in a dyad (Initiator Dem $\times$ Dissimilarity) in order to assess whether autocracies or democracies are more likely to initiate MIDs against states with differing polities.

To ensure the robustness of results and model fit, we included a further set of control variables. Significantly related to conflict are national material capabilities (Singer 1987). In both, the directed and the undirected analyses, we include a dyadic measurement of the balance of material power. The variable capability ratio spans from .5 (equal capabilities) to 1 (preponderance). In addition, we control whether or not dyads are composed of two minor powers using the binary variable both minor powers (Oneal and Russett 1999b). Concerning the directed analyses, we further include a variable measuring the aggressor's material capabilities divided by the sum of both the initiator's and the target's national capabilities (Initiators $p($ win $)$ ). Contrary to the capability ratio, this alternative measurement of the balance of power captures the preponderance of the aggressor over the defender and might be interpreted as the "naive probability of the initiator winning the conflict" (Bennett and Stam 2000a, 669).

Several studies show that economic interdependence and trade openness reduce a country's probability of conflict involvement (Oneal and Russett 1999b; Maoz 2009; Bussmann 2010). We measure commercial dependence by the number of exports and imports as a portion of national GDP (Dyadic trade dependence). Since various studies find that geographic proximity makes MID onsets more likely, we also include the variables Contiguity and Distance (log) that account for whether or not two states share a land border and the natural logarithm of the distance between both countries' capitals cities (Bennett and Stam 2000a). To control for the effects of unobserved factors inherent to different geographical regions, we created regional dummies for Europe, the Middle East as well as Asia, Africa, or the Western Hemisphere (Small and Singer 1982). Finally, we included a variable reflecting the duration since the last militarized dispute outbreak and calculated polynominals to minimize problems of temporal dependence (Beck, Katz, and Tucker 1998; Carter and Signorino 2010).

\section{Quantitative Findings}

Table 1 shows the effects of oil production and petroleum reserves as well as several control variables on the risk of MID involvement using undirected dyads. In line with the conventional wisdom, oil-abundant countries in fact seem more likely to participate in MIDs. However, a comparison across the different models also reveals that the statistical relationship between oil and conflict is highly contingent on the way in which oil is conceptualized and measured. Whereas high 


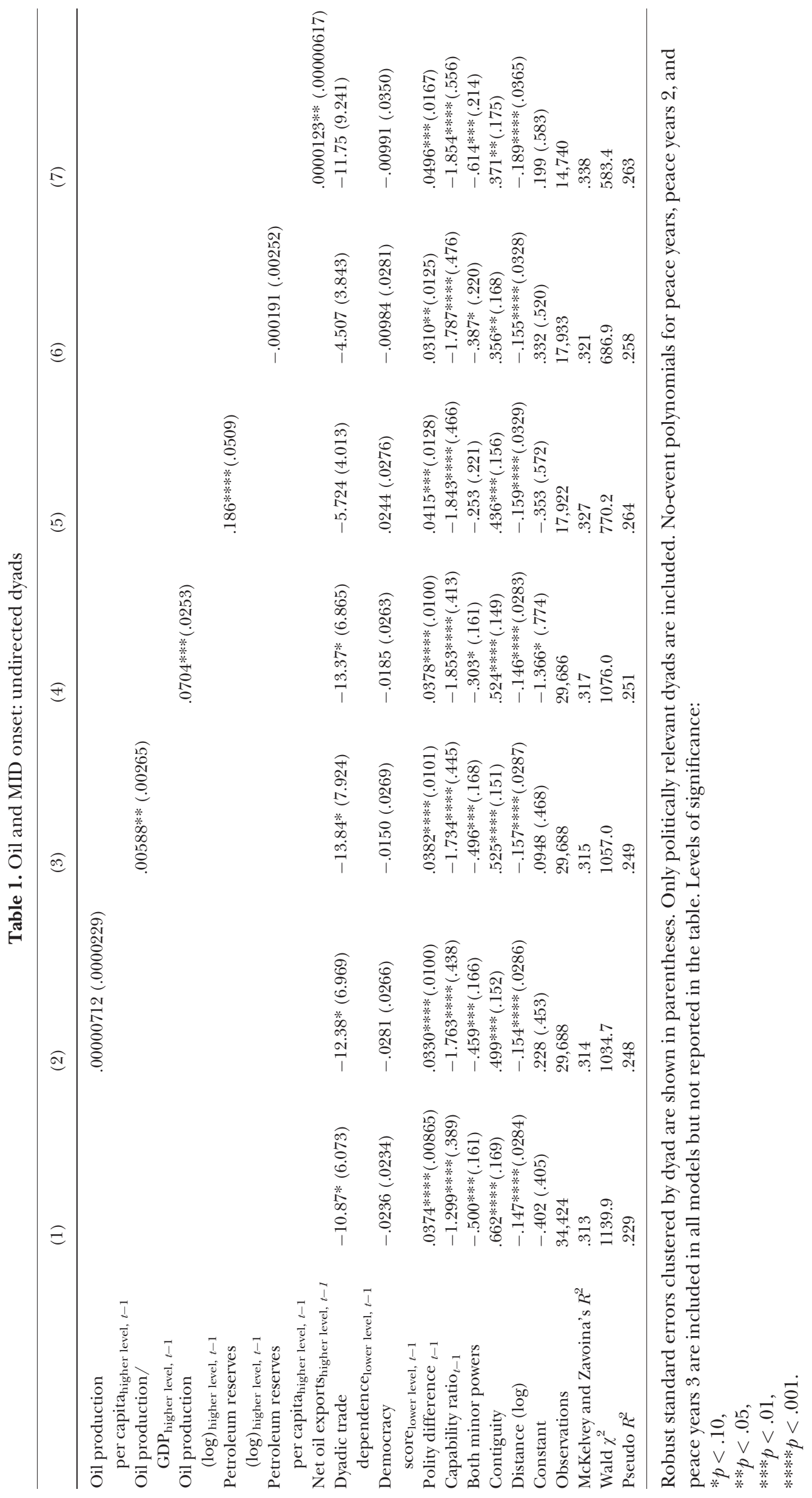


(a)

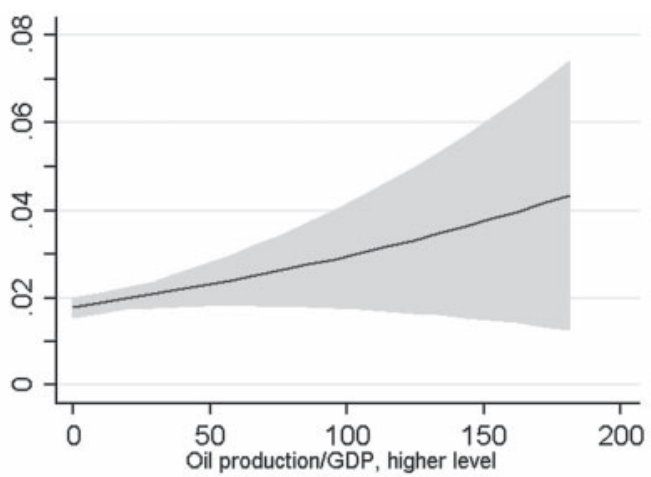

(c)

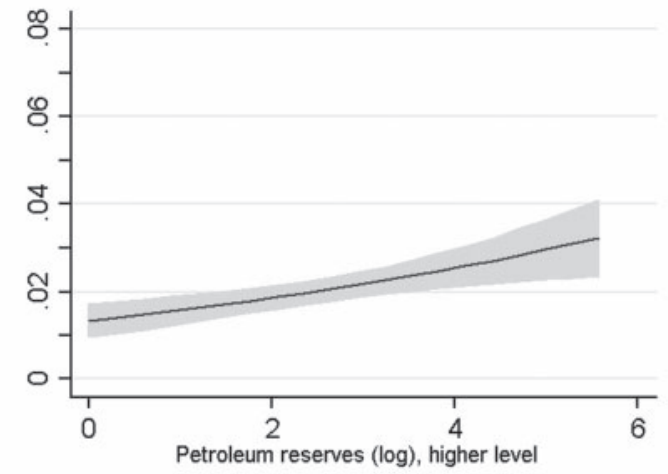

(b)

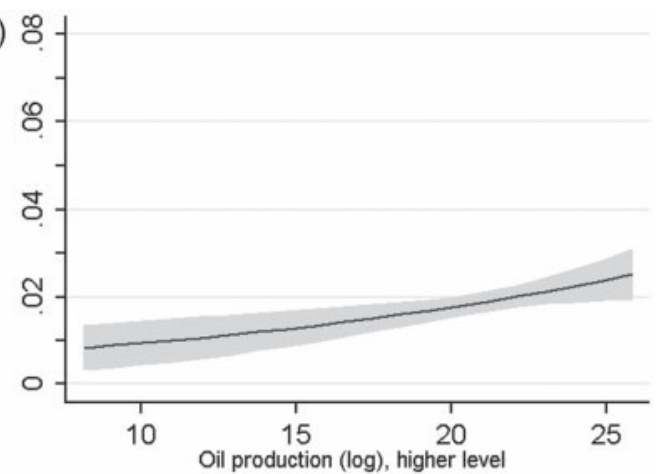

(d)

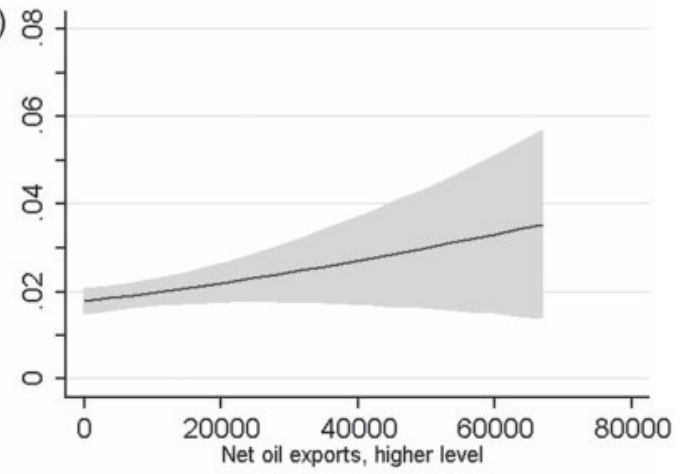

$95 \%$ confidence intervals shaded in grey.

Figure 1. Predictive Margins of Oil on MID Onset (undirected dyads).

per capita levels of petroleum wealth is statistically unconnected to a country's propensity of dispute involvement, the coefficients of the variables Oil production/ GDP and Oil production (log) as well as Petroleum reserves (log) and Net oil exports are positively and significantly related to conflict involvement (see Table 1 ) ${ }^{20}$ It is important to note that the varying effects of the alternative oil measurements are of rather theoretical importance than just a mere consequence of different sample sizes. Reestimating the models using a sample of observations for which all data are available yields qualitatively similar results. ${ }^{21}$

Figure 1 illustrates the average marginal effects on MID involvement of the different statistically significant oil measurements. Overall, the plots confirm that higher levels of oil production (e.g., the logarithm of absolute production and production's proportion to GDP), petroleum reserves and net oil exports are related to higher probabilities of dispute involvement. For instance, moving from the minimum to the maximum of Oil production (log) and Petroleum reserves (log) approximately doubles the risk of conflict participation. In the case of the unlogged production data, the risk of conflict involvement increases even three-fold from approximately two to six percent (see Figure S2 of the Online Supporting Material).

\footnotetext{
${ }^{20}$ Estimation results for models using the unlogged value of oil production and petroleum reserves as well as the lower level of a dyads resource measurement are reported in Table S5 in the Online Supporting Material. The results corroborate the findings of Table 1 . Drawing on a sample including all dyads instead of only the politically relevant dyads as well as controlling for regional effects does not change the results qualitatively (see Tables S6 and S7 of the Online Supporting Material). For similar tests using directed dyads as units of analyses refer to Tables S18-S20 of the Online Supporting Material.

${ }^{21}$ Tables S4 and S15 of the Online Supporting Material report the estimation results employing a sample of nonmissing observations. Note that the sample size drops considerably. This is due to the limited availability of the net oil exports variable that is only available for a large number of countries starting in the late 1980s (see descriptive statistics in Table S2 and the correlation matrix in Table S3 of the Online Supplementary Material).
} 
Changing the units of analysis and moving to the directed dyads corroborates the findings and provides a more nuanced view on the effects of oil on a country's likelihood of being an MIDs aggressor (Side A) or target (Side B). Several authors question the validity of the distinction between the dispute initiator and the target state of an MID (e.g., Ghosn, Palmer, and Bremer 2004). However, we need to resort to a directed dyad framework in order to gain some initial insight of the relation between oil and a state's role in a dispute.

Concerning dispute initiators, the data confirm that countries with higher levels of oil production are in fact more likely to "fire the first shot" in a military encounter. ${ }^{22}$ The coefficient of Oil production $(\log )$ is positive and statistically significant in the case of Side A (the MID initiator), but not in the case of Side B (see Model 11 of Table 2). We further suggested that the availability of large petroleum reserves makes interstate conflict more likely, especially when located in contested border areas, as they drive greedy governments to attack petroleumabundant countries. The data render support to this assumption. The coefficients of both Petroleum reserves (log) and Petroleum reserves per capita are positive in the case of MID target countries (see Models 12 and 13 of Table 2).

Plotting the marginal effects of the oil variables which reached statistical significance in the directed dyadic set-up of the analysis further illustrates the statistical relationship between conflict involvement and oil production/reserves (see Figure S3 of the Online Supporting Material). On the one hand, while larger amounts of national oil production make it nearly two times more likely that a country is the aggressor of a militarized dispute (Side A), higher levels of oil production have virtually no impact on a country's risk of being a conflict target (Side B). On the other hand, higher amounts of petroleum reserves, in particular if measured in per capita terms, lead to an increased risk of suffering from foreign military aggressions.

The latter finding applies in particular to small oil-abundant countries. This becomes evident when splitting the sample according to Side B's population size in small and big petrostates (greater than or less than four million inhabitants; see Table S23 of the Online Supporting Material). Smaller, oil-rich states especially tend to be the target of international conflicts while they are at the same time less likely to initiate them. Observations driving these results include oil-rich countries in the Middle East (e.g., Kuwait, United Arab Emirates, Oman, and Bahrain) as well as some cases in Africa and Latin America (e.g., Trinidad and Tobago, Gabon).

As we have argued in other parts of this paper, we believe that high levels of resource abundance not only drive the outbreak of deadly disputes between states, but also result in foreign policy aggressions and low-intensity military adventures (i.e., without casualties). Petrostate leaders relying on a well-developed military apparatus or enjoying the indulgence of an oil-dependent international community may engage in lower intensity international disputes characterized by the show or threat of force. While oil, in general, is likely to produce minor forms of interstate disputes in most of the cases, we assume that conflicts involving petroleum reserves may be more severe especially when conflict parties strive for the ownership of resources in border areas.

To test this assumption, the next analysis distinguishes between fatal and nonfatal interstate disputes. Controlling for the severity of disputes by reestimating the

\footnotetext{
${ }^{22}$ Using an alternative conceptualization of "Side A" based on the existence of revisionist objectives does not alter the results. Tables S16 and S17 of the Online Supporting Material report the finding for dispute originators on Side A of a dyad that are states that have been "dissatisfied with the existing status quo prior to the onset of a militarized interstate dispute" and where revisionism relates to territories, regimes, and policies (Jones, Bremer, and Singer 1996, 178; see also Ghosn, Palmer, and Bremer 2004, 138).
} 


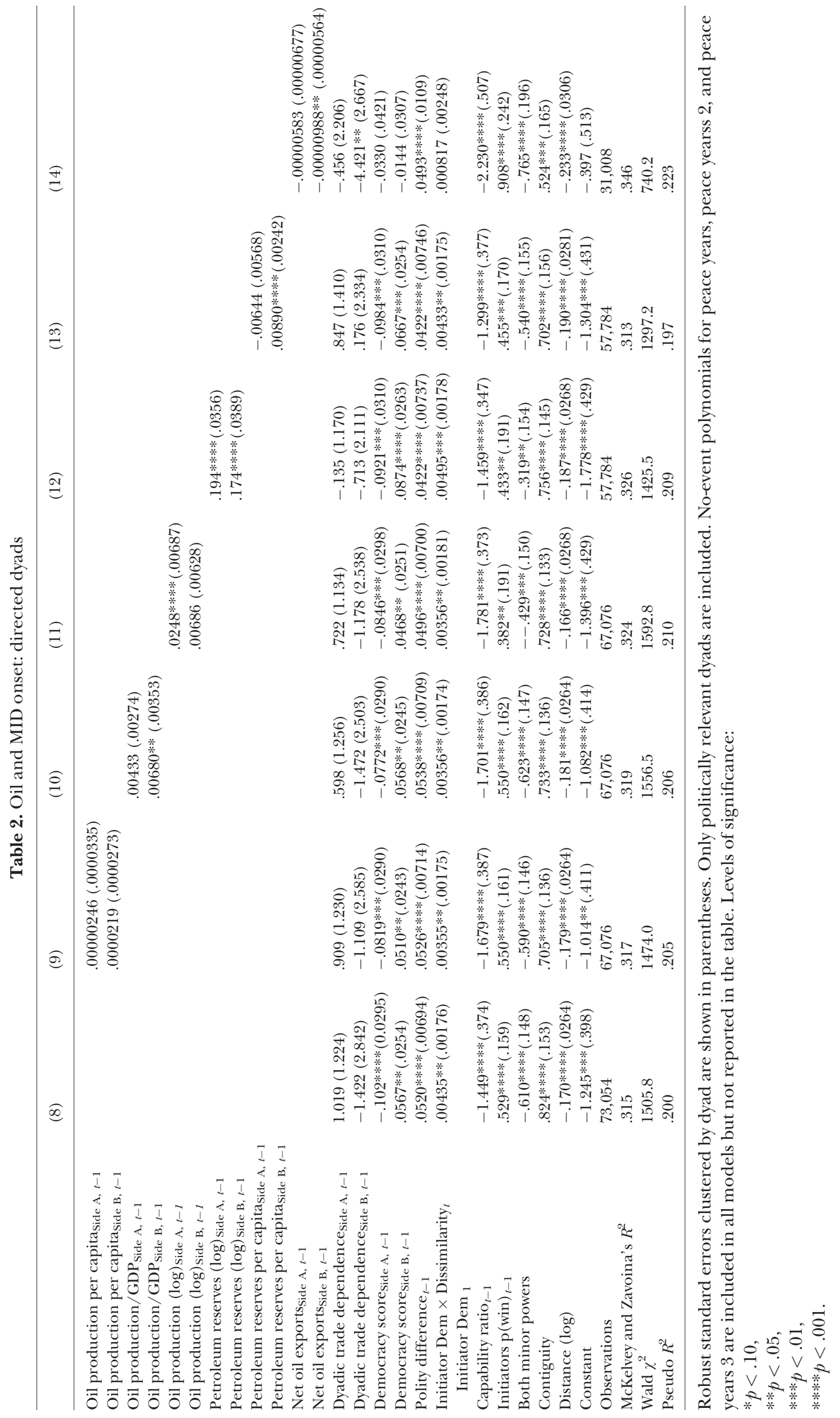


models of Tables 1 and 2 using different MID subsamples according to the occurrence of battle-related deaths gives initial confirmation to our assumptions: high levels of Oil production (log), Petroleum reserves $(\log )$, and, albeit to a somehow lesser degree, Oil production/GDP and Net oil exports are associated with the outbreak of nonfatal disputes, but lose statistical significance when the samples are restricted to deadly conflicts. Only large petroleum reserves in absolute terms and, in the case of Side B of the dyadic analyses, also large per capita reserves are robustly and positively correlated with a state's involvement in MID onsets throughout the different subsamples and show an increasing impact on dispute onset in the case of conflicts with higher levels of fatality. ${ }^{23}$ Oil reserves seem to especially drive the classical "resource war" outlined in the theoretical section. Compared with real production figures, hydrocarbon reserves seem to be more important for explaining disputes over resources located near countries' borders or the rapacious assault of greedy neighbors.

Finally, the control variables are largely in line with the findings of previous studies. Regarding the undirected analyses, Dyadic trade dependence is negatively related to MID onset. Similarly, the more democratic both states of a dyad are, the lower the risk that both countries will engage in a militarized dispute against each other. Of the remaining control variables, Polity difference and Contiguity are on average positively related with dispute onset. The closer states are in geographic terms and the farer away from each other in terms of political regime types, the more likely a military conflict becomes. If material capabilities are equally distributed among both parties of a dyad and if both states are minor powers, conflicts become less likely instead.

One major concern with the results reported above, however, is the possibility that they are driven by single influential cases. Dyads enjoying high levels of oil production and more frequently engaging in interstate disputes may be heavily influencing our estimates. In particular, the United States and Russia (formerly Soviet Union) exhibit very large oil production volumes and-especially during the Cold War period-have initiated a high number of militarized disputes. This may distort our results, as the conflicts fought by both countries during the Cold War era might have little, if anything, to do with oil. Thus, we recalculated the models of Tables 1 and 2 excluding the United States and Russia. The results remain largely unaltered in the case of the samples including all conflicts or nonfatal disputes. If the MID subsample of fatal disputes is employed, only large petroleum reserves continue to play a significant role for the explanation of conflict onset. Thus, the evidence that large oil producers exhibit a particularly aggressive foreign policy behavior is further supported when controlling for the impact of highly influential cases. ${ }^{24}$

In a further robustness check, we included a dichotomous variable measuring whether a government can be considered "revolutionary" or not in both the directed and the undirected dyadic estimations. ${ }^{25}$ Even after controlling for revolutionary governments, many of our oil variables remain statistically significant. ${ }^{26}$ Thus, contrary to Colgan's (2010) conclusion, we find that the impact of oil on interstate disputes is not necessarily contingent on the existence of a revolutionary leader.

\footnotetext{
${ }^{23} \mathrm{We}$ compare four subsamples of militarized interstate disputes that comprise nonfatal, fatal, and disputes with low and high levels of fatalities, respectively. The results for nonfatal and fatal disputes are reported in Tables S8 and S9 (undirected dyads) and Tables S21 and S22 of the Online Supporting Material.

${ }^{24}$ To explore whether our findings can be traced back to a few powerful outliers, we also conducted a more formal outlier analysis employing Cook's distance measure. After excluding observations with a high leverage, our oil measures still had a comparable and significant impact on MID onset.

${ }^{25}$ The variable was taken from Colgan (2010). We included it both as a regular control variable and as an interaction term with our oil measures.

${ }^{26}$ See Tables S11, S12, S13, S25, and S27 of the Online Supporting Material.
} 
As standard logit or probit estimations may produce biased coefficients when binary dependent variables measure the occurrence of "rare events," all models were reestimated using "rare event logit models" (see King and Zeng 2001). Results did not change considerably. We further tested our main assumptions using the monadic level of analyses. ${ }^{27}$ Following the argument made by Colgan (2013b, 170-71) that petroleum played an increasing role in the onset of international disputes in the "modern age of oil" which began with the Arab oil crisis, we also restricted our main models using undirected and directed dyads to the period from 1973 to 2001 and reevaluated them. The estimations yielded qualitatively comparable results and in some cases even higher coefficients for our main explanatory variables. The exclusion of the Gulf War of 1990/1991, which involves several petroleum-conflict dyads following the high number of countries joining the coalition forces, did also not change our results considerably.

\section{Discussion of Results}

Summarizing the results presented above, our findings have four major implications. First, resources such as oil may indeed instigate aggressive foreign policy behavior in the form of MIDs as shown by our nondirected dyadic analysis. Our estimations find statistical evidence that large absolute amounts of oil production or reserves and of net oil exports are conducive to MID participation. It seems that not only oil dependence (as shown in De Soysa, Gatzke, and Lie 2009), but also oil abundance increases the risk of being involved in a militarized dispute. At the same time, our analysis also revealed that high per capita figures of petroleum revenues are not conducive to MID involvement in general.

As outlined in the theoretical section, high absolute amounts of oil rents or large oil exports could possibly enhance states' capabilities of building up large military apparatuses, increase countries' economic value for the resource-hungry international community, or pose a greater risk of suffering domestic conflicts. On the other hand, higher per capita levels could help state leaders to oppress or buy off political opposition, to enjoy more fiscal autonomy, to weaken pressure of legitimation, and to face less political veto points, allowing them to pursue foreign policy adventurism. Following the results of our research design employing different oil measures, the paper's second implication is that classical rentier state mechanisms predicting a higher political autonomy of petrostate leaders may be less powerful in explaining the onset of MIDs. This interpretation is further corroborated by the inclusion of intervening variables in order to test the possible theoretical pathways linking oil to interstate conflict (e.g., military buildups, weak state-society linkages, and the interplay between international and intrastate conflict). While military buildups and the incidence of intrastate violence seem more conducive to MID involvement, we find that variables accounting for weak state-society linkages are not related to militarized disputes in the hypothesized way. ${ }^{28}$

Third, our analyses revealed that while high absolute oil production levels are strongly correlated with nonfatal MIDs, only petroleum reserves (in absolute terms) seem to further the likelihood of fatal MIDs. We believe that disputes involving petroleum-rich countries as measured by available petroleum reserves are more severe as they often involve conflict parties striving for the ownership of resources in border areas. The highly significant relationship between oil reserves

\footnotetext{
${ }^{27}$ As one may also argue that linking oil with domestic conditions (e.g., weak state-society relationships, internal violence) alludes to monadic theories and should be investigated at the state-level of analysis, we checked the robustness of our results using state-years as the unit of analysis. The results are reported in Tables S28-S30 of the Online Supporting Material.

${ }^{28}$ The results are presented in Table S14 of the Online Supporting Material.
} 
and all subtypes of MIDs lends positive evidence to the existence of classical "resource wars" so often propagated by experts and the media.

Finally, the estimations on directed dyadic data showed that countries enjoying a high absolute oil production (or oil reserves) more commonly initiate international disputes. In addition, states exhibiting large petroleum reserves (both in absolute and per capita terms) are more frequently the target of military hostilities by other countries. Smaller oil-rich states seem especially more susceptible to suffering external aggressions. Countries such as Kuwait, Bahrain, Oman, the United Arab Emirates, and Trinidad and Tobago have repeatedly faced belligerent aggressors from abroad.

\section{Conclusion}

In this paper, we sought to contribute to a still underdeveloped research agenda in various ways. Foremost, we tried to advance our understanding of why oil may promote MIDs by focusing on particular causal pathways. For this purpose, we relied on different research designs (nondirected and directed dyadic data), employed different oil measures, and differentiated between various forms of military interstate disputes (e.g., fatal vs. nonfatal conflicts). Our estimations on undirected dyads showed that MID involvement is more likely whenever states exhibit a large absolute oil production (or oil reserves), large oil exports, or are characterized by high oil dependency.

Regression models on directed dyads further indicated that those countries enjoying a high absolute oil production (and oil reserves) are more inclined to adapt an aggressive foreign policy behavior and initiate international conflicts. Large petroleum deposits are associated with more violent forms of interstate disputes and seem to make countries more susceptible to foreign military actions. In contrast, states enjoying a high per capita oil production (or oil reserves) are not more likely to initiate militarized disputes.

This finding suggests that domestic political conditions associated with weak state-society linkages and the rentier state seem to play a subordinate role in explaining the oil conflict nexus. Rather, we find first evidence that investments in large military apparatuses, the indulgence of the international community, and the susceptibility to suffering internal violence may better explain petrostates' higher dispute involvement risk. Further empirical evidence has been found for another common explanation linking oil-rich states to increased interstate conflict participation: so-called resource wars involving disputes over natural resources in frontier areas or within disputed maritime borders.

Finally, our results suggest that not only countries that combine a high economic dependence on oil exports with the existence of a "revolutionary government" more frequently engage as the aggressor in militarized disputes (Colgan 2010,682 ). Our empirical results turned out to be robust to the inclusion of a revolutionary state variable, indicating that oil by itself seems to be a sufficient predictor for MID participation.

Despite providing some plausible explanations for the hypothesized relationships, we want to stress that our analysis cannot be viewed as a definitive test for specific causal channels. Our estimations should be viewed as indicative (rather than authoritative) for a particular class of mechanisms. Much more quantitative and qualitative work seems needed to better understand the link between resources and interstate conflicts.

\section{References}

Ali, Hamid E., and Omnia A. Abdellatif. 2015. "Military Expenditures and Natural Resources: Evidence from Rentier States in the Middle East and North Africa." Defence and Peace Economics 26: 5-13. 
Basedau, Matthias, and Jann Lay. 2009. "Resource Curse or Rentier Peace? The Ambiguous Effects of Oil Wealth and Oil Dependence on Violent Conflict." Journal of Peace Research 46: 757-76.

Basedau, Matthias, and Thomas Richter. 2014. "Why Do Some Oil Exporters Experience Civil War But Others Do Not? Investigating the Conditional Effects of Oil." European Political Science Review 6: 549-74.

Beck, Nathaniel, Jonathan J. Katz, and Richard Tucker. 1998. "Taking Time Seriously in Binary TimeSeries Cross Section Analysis.” American Journal of Political Science 42: 1260-88.

Bellin, Eva. 2004. "The Robustness of Authoritarianism in the Middle East: Exceptionalism in Comparative Perspective." Comparative Politics 36: 139-57.

Bennett, D. Scott, and Allan C.Stam. 2000a. "Research Design and Estimator Choices in the Analysis of Interstate Dyads: When Decisions Matter." Journal of Conflict Resolution 44: 653-85.

Bennett, D. Scott, and Allan C. Stam. 2000b. "EUGene: A Conceptual Manual." International Interactions 26: 179-204.

Besley, Timothy, and Torsten Persson. 2010. "State Capacity, Conflict, and Development." Econometrica 78: $1-34$.

Boehmer, Charles R. 2008. "A Reassessment of Democratic Pacifism at the Monadic Level of Analysis." Conflict Management and Peace Science 25: 81-94.

Bratthwaite, Alex. 2006. "The Geographic Spread of Militarized Disputes." Journal of Peace Research 43: 507-22.

Bussmann, Margit. 2010. "Foreign Direct Investment and Militarized International Disputes." Journal of Peace Research 47: 143-53.

Carter, David B., and Curtis S.Signorino. 2010. "Back to the Future: Modeling Time Dependence in Binary Data." Political Analysis 18: 271-92.

Caselli, Francesco, Massimo Morelli, and Dominic Rohner. 2013. "The Geography of Inter-State Resource Wars.” NBER Working Paper No. 18978.

Colgan, JefF D. 2010. "Oil and Revolutionary Governments: Fuel for International Conflict." International Organization 64: 661-94.

2013a. Petro-Aggression: When Oil Causes War. New York: Cambridge University Press. 2013b. "Fueling the Fire. Pathways from Oil to War." International Security 38: 147-80.

Collier, Paul, and Anke Hoeffler. 2004. "Greed and Grievance in Civil War." Oxford Economic Papers 56: 563-95.

Cotet, Anca M., And Kevin K. Tsui. 2013. "Oil and Conflict: What Does the Cross Country Evidence Really Show?” American Economic Journal: Macroeconomics 5: 49-80.

De Soysa, Indra, Gartzke, Eric, and Tove Grete Lie. 2009. "Blood, Oil, and Strategy: How Petroleum Influences Interstate Disputes." Unpublished manuscript.

Englehart, Neil A. 2009. "State Capacity, State Failure, and Human Rights." Journal of Peace Research 46: $163-80$.

FJelde, Hanne. 2009. "Buying Peace? Oil Wealth, Corruption and Civil War 1985-1999.” Journal of Peace Research 46: 199-218.

Fordham, Benjamin O. 2004. "A Very Sharp Sword: The Influence of Military Capabilities on American Decisions to Use Force.” Journal of Conflict Resolution 48: 632-56.

Gandhi, Jennifer, and AdAm Przeworski. 2006. "Cooperation, Cooptation, and Rebellion under Dictatorships." Economics and Politics 18: 1-26.

Ghosn, Faten, Glenn Palmer, and Stuart Bremer. 2004. "The Mid3 Data Set, 1993-2001: Procedures, Coding Rules, and Description.” Conflict Management and Peace Science 21: 133-54.

Gleditsch, Kristian S., Idean Salehyan, and Kenneth Schultz. 2008. "Fighting at Home, Fighting Abroad: How Civil Wars Lead to International Disputes." Journal of Conflict Resolution 52: 479-506.

Herb, Michael. 2005. "No Representation Without Taxation? Rents, Development, and Democracy." Comparative Politics 37: 297-316.

Hobson, John Atkinson. 1965. Imperialism: A Study. Ann Arbor, MI: University of Michigan Press.

Humphreys, Macartan. 2005. "Natural Resources, Conflict and Conflict Resolution." Journal of Conflict Resolution 49: 508-37.

Huntington, Samuel P. 1991. The Third Wave: Democratization in the Late 20th Century. Norman, OK: University of Oklahoma Press.

Jaggers, Keith, and Ted R. Gurr. 1995. "Tracking Democracy's Third Wave with the Polity III Data." Journal of Peace Research 32: 469-82.

Jones, Daniel M., Stuart M. Bremer, and David J. Singer. 1996. "Militarized Interstate Disputes, 1816 1992: Rationale, Coding Rules, and Empirical Patterns.” Conflict Management and Peace Science 15: 163-213. 
King, Gary, and Langche Zeng. 2001. "Logistic Regression in Rare Events Data.” Political Analysis 9: 137-63.

Klare, Michael T. 2001. Resource Wars. The New Landscape of Global Conflict. New York: Metropolitan Books.

- 2008. Rising Powers, Shrinking Planet. The New Geopolitics of Energy. New York: Metropolitan books.

Le Billon, Philippe. 2004. "The Geopolitical Economy of Resource Wars." Geopolitics 9: 1-28.

- 2012. Wars of Plunder. Conflicts, Profits and the Politics of Resources. London: Hurst \& Company.

Le Billon, Philippe, and Fouad El Kathib. 2004. "From Free Oil to 'Freedom Oil': Terrorism, War and US Geopolitics in the Persian Gulf." Geopolitics 9: 109-37.

Mahdavy, Hussern. 1970. "The Patterns and Problems of Economic Development in Rentier States: The Case of Iran." In Studies in Economic History of the Middle East from the Rise of Islam to the Present Day, edited by Michael Cook. London: Oxford University Press pp. 428-467.

MaOz, ZeEv. 2009. "The Effects of Strategic and Economic Interdependence on International Conflict across Levels of Analysis." American Journal of Political Science 53: 223-40.

McDonald, Patrick. 2007. "The Purse Strings of Peace.” American Journal of Political Science 51: 569-82.

Mearsheimer, John J. 2001. The Tragedy of Great Power Politics. New York: Norton.

Most, Benjamin, and Harvey Starr. 1989. Inquiry, Logic and International Politics. Columbia, SC: University of South Carolina Press.

Newland, Kathleen. 1995. "The Impact of US Refugee Policies on US Foreign Policy: A Case of the Tail Wagging the Dog?” In Threatened Peoples, Threatened Borders: World Migration and US Policy, edited by Michael S. Teitelbaum and Myron Weiner. New York: W.W. Norton, pp. 190-214.

Oneal, John R., and Bruce Russett. 1999a. "The Kantian Peace: The Pacific Benefits of Democracy, Interdependence, and International Organizations, 1885-1992.” World Politics 52: 1-37.

— 1999b. "Assessing the Liberal Peace with Alternative Specifications: Trade Still Reduces Conflict.” Journal of Peace Research 36: 423-42.

Oneal, John R., Bruce Russett, and Michael L. Bernbaum. 2003. "Causes of Peace: Democracy, Interdependence, and International Organizations, 1885-1992.” International Studies Quarterly 47: 371-93.

Peters, Susanne. 2004. "Coercive Western Energy Security Strategies: 'Resource Wars' As a New Threat to Global Security." Geopolitics 9: 187-212.

Ross, Michael L. 2006. "A Closer Look at Oil, Diamonds, and Civil War." Annual Review of Political Science 9: 265-300.

—. 2012. The Oil Curse: How Petroleum Wealth Shapes the Development of Nations. Princeton, NJ: Princeton University Press.

—. 2013. "Oil and Gas Data, 1932-2011." Version 2. Accessed September 17, 2013. http://hdl.han dle.net/1902.1/20369.

Salehyan, Idean. 2008a. "No Shelter Here: Rebel Sanctuaries and International Conflict." The Journal of Politics 70: 54-66.

- 2008b. "The Externalities of Civil Strife: Refugees as a Source of International Conflict." American Journal of Political Science 52: 787-801.

Sample, Susan. 1998. "Military Buildups, War and Realpolitik. A Multivariate Model." Journal of Conflict Resolution 42: 156-75.

Schultz, Kenneth A. 2010. "The Enforcement Problem in Coercive Bargaining: Interstate Conflict Over Rebel Support in Civil Wars." International Organization 64: 281-312.

Sharp, Travis. 2007. "Resource Conflict in the Twenty-First Century." Peace Review 19: 323-30.

Singer, DAVID J. 1987. "Reconstructing the Correlates of War Dataset on Material Capabilities of States, 1816-1985.” International Interactions 14: 115-32.

Small, Melvin, and J. David Singer. 1982. Resort to Arms: International and Civil Wars, 1816-1980. Beverly Hills, CA: Sage Publications.

Souva, Mark, and Brandon Prins. 2006. "The Liberal Peace Revisited: The Role of Democracy, Dependence, and Development in Militarized Interstate Dispute Initiation, 1950-1999." International Interactions 32: 183-200.

Strüver, Georg. 2010. "Too Many Resources or Too Few? What Drives International Resource Conflicts?” GIGA Working Paper No. 147 Hamburg, Germany: German Institute of Global and Area Studies.

Teorell, Jan, Marcus Samanni, Nicholas Charron, Sören Holmberg, and Bo Rothstein. 2013. The Quality of Government Dataset (Version 20dec13).The Quality of Government Institute, University of Gothenburg. Accessed March 1, 2014. http://www.qog.pol.gu.se. 
Ulfelder, Jay. 2007. "Natural-Resource Wealth and the Survival of Autocracy." Comparative Political Studies 40: 995-1018.

Wegenast, Tim. 2013. "Opening Pandora's Box? Inclusive Institutions and the Onset of Internal Conflict in Oil-Rich Countries." International Political Science Review 34: 392-410.

Wright, Joseph, Erica Frantz, and Barbara Geddes. 2015. "Oil and Autocratic Regime Survival." British Journal of Political Science 45: 287-306.

Zweig, David, and Jianhai Bi. 2005. “China’s Global Hunt for Energy.” Foreign Affairs 84: 25-38. 